\title{
LEGAL REGULATION OF THE FINANCIAL SUPPLY OF THE CONSTITUTIONAL COURT OF UKRAINE
}

\author{
Ian Bernaziuk ${ }^{1}$, Nataliia Kovalenko²
}

\begin{abstract}
The aim of the article is to study the history and modernity, the doctrine and practice of legal regulation of financial support of the Constitutional Court of Ukraine. The subject of the study is the legal regulation of the financial support of the Constitutional Court of Ukraine. Methodology. Scientific research is based on the use of philosophical, general scientific and special scientific methods and techniques of scientific knowledge. The dialectical method allowed considering the legal regulation of the financial support of the functioning of the Constitutional Court of Ukraine in development and interaction with other social and legal phenomena. The historical method is aimed at reconstructing the genesis of legal regulation of the financial support of the Constitutional Court of Ukraine at various stages of its formation. The formal legal method enabled to characterize the specificities of the legal regulation of financial support of the Constitutional Court of Ukraine by legal constructions and legal terminology. Comparative legal method contributed to the study of the specifics of the legal regulation of financial guarantees of the independence of constitutional justice bodies in certain countries of the world. The results of the study revealed that the characteristic feature of socio-political transformations in modern Ukrainian society is ongoing reformation of constitutional justice, one task of which is to strengthen the financial independence of the CCU as potentially the most effective institution for the protection of human and civil rights and freedoms, establishment of legal, constitutional Ukraine. Practical implications. In the study, firstly, the views of experts on the legal regulation and practice of financing the Constitutional Court of Ukraine as a body of constitutional jurisdiction were considered; secondly, the specificities of legal regulation of financing of the Constitutional Court of Ukraine before the reform of constitutional justice in 2016-2017 were studied; thirdly, the current state and prospects of improving the financial support of the Constitutional Court of Ukraine were analysed. Relevance/originality. On the basis of a comprehensive study of the constitutional doctrine, domestic and foreign legislation and practice of its implementation, directions of strengthening the financial independence of the Constitutional Court of Ukraine are proposed.
\end{abstract}

Key words: constitutional justice, Constitutional Court of Ukraine, reform of constitutional justice, independence of Constitutional Court of Ukraine, financial support of Constitutional Court of Ukraine.

JEL Classification: K3, K13

\section{Introduction}

Modern efforts on the transformation of Ukraine into a legal democratic European state are impossible without establishing the supremacy of the current Constitution of Ukraine. Therefore, it is logical that the issue of proper legal protection of the Basic Law is extremely relevant, interesting, though difficult. Indeed, the problem of legal protection of the Constitution, which arose almost immediately after the formation of original ideas of constitutionalism and first constitutional acts, continues to be one of the main objects of scientific discussion in the modern theory and practice of constitutional law (Fedorenko, 2015). According to the principles of a democratic, legal, social state, the constitutional justice of the Constitutional Court of Ukraine serves as

Corresponding author:

${ }^{1}$ Supreme Court of Ukraine, Ukraine.

E-mail: bernaziuk1979@gmail.com

${ }^{2}$ Supreme Court of Ukraine, Ukraine.

E-mail:nv417170@gmail.com the guarantor of their consistent implementation and formation of real democracy. The competence of the Constitutional Court of Ukraine (hereinafter, the CCU, the Court) enables to confirm the significant potential for a direct effect of the Constitution of Ukraine. It is an arbitrator between the branches of power, ensuring the stability and proper functioning of public authorities and local self-government bodies, guaranteeing constitutionality for legal act adoption. At present, the CCU is a body of constitutional jurisdiction, which significantly influences the national legal system of Ukraine and occupies an important place among the jurisdictional institutions because it determines the condition and dynamics of protecting human and civil rights and freedoms (Kuzmenko, 2012). 


\section{The aim of the article}

One of the main reasons for the weakening of the CCU authority over the last decade is the lack of guarantees of the independence of its activities, in particular, financial ones. Therefore, the study of the history and modernity, the doctrine and practice of legal regulation of the financial support of the CCU acquire a special relevance, which is the aim of this scientific article. For its successful implementation, the following tasks should be solved: first, to consider the views of specialists on legal regulation and practice of financing the CCU as a body of constitutional jurisdiction; second, to analyse the legal regulation of financing of the Constitutional Court of Ukraine before the reform of the constitutional justice in 2016-2017; third, to study the current state and prospects for improving the financial support of the CCU.

Literature review. It should be noted that some aspects of financial (budget) provision of the CCU functioning were interpreted in the works of M. I. Koziubra, P. F. Martynenko, M. D. Savenko, M. V. Savchyn, M. F. Selivon, V. E. Skomorokha, I. D. Slidenko, V. M. Shapoval, S. V. Shevchuk.

\section{The main material}

Thus, effective performance of the CCU's tasks and functions determined in accordance with the current domestic legislation is possible only on condition of sufficient financial support of this body, which is a guarantee of its independent functioning. The independence of the CCU in exercising its authorities is provided by various guarantees, that is, a set of specific conditions, means, and methods. Material and financial independence and autonomy of the CCU are the basis for the realization of its independence as a whole (Chupryna, 2006).

According to V.Ye. Skomorokha, the most important element of the $\mathrm{CCU}$ independence is proper conditions for its activities and functioning. This is provided by the financing of the Constitutional Court, remuneration of judges, their pensions, etc. The Constitution of Ukraine charged the state to finance, establish proper conditions for the Constitutional Court and judges' performance providing for the expenditures for the maintenance of this institution in the State Budget of Ukraine (Article 130 of the Constitution of Ukraine), not having determined a clear mechanism for this norm implementation (Skomorokha). The experience of the Parliament of Ukraine gives evidence on the use of the "wallet rights" to influence the independence of the Court. In particular, by adopting the State Budget of Ukraine for 1998, the Verkhovna Rada of Ukraine, "without a vote", without any preliminary discussion and available reasons, contrary to the recommendations of the Government and the Budget Committee, without consulting the leadership of the CCU, reduced the state expenditures for the maintenance of the Court almost by $40 \%$. Nothing of this kind has taken place in relation to any other authority (Skomorokha, 2006). The Law of Ukraine "On the Constitutional Court of Ukraine" as of October 16, 1996, does not contain such a mechanism as well, besides Article 31 provides for that the proposals regarding the financing of the Constitutional Court and the draft of the corresponding estimations should be submitted by the Head of the Court to the Cabinet of Ministers of Ukraine and the Verkhovna Rada of Ukraine when drafting the State Budget of Ukraine. The proposals are not obligatory for the bodies, to which they are submitted and, therefore, they determine financing at their discretion that affects the independence of the CCU and its judges. According to V. Ye. Skomorokha, in the Law of Ukraine "On the Constitutional Court of Ukraine", it is necessary to determine the specific percentage of national gross profits allocated to the financing of the Court, and mandatory consideration of the draft estimations proposed by the Head of the CCU for the government and parliament. The total financing proposed by the CCU can be reduced only in cases of limiting the financing of all the highest bodies of state power. Reducing financing should be adequate, that is, for a clearly defined and equal percentage for all. The draft estimations should be made in presence of judges and they should monitor its implementation, which will limit the internal impact on judges by providing them with a bonus, material assistance or allocation of funds for welfare needs. Approval of the draft budget for each year and hearing of the quarterly information of the Head of the CCU on the use of budgetary funds at the Court is provided for in paragraph 8 of the CCU Rules. However, in practice, these provisions are not performed by the CSU (Skomorokha). The total remuneration of the Head of the CCU cannot exceed the total remuneration of judges by more than $10 \%$. A greater difference in wages diminishes the importance of the judge's judicial power in constitutional proceedings (Skomorokha).

The practice of financing the Constitutional Court of Italy shows that one of the conditions for its independence is financial independence. Any restriction of this independence is recognized by the court as unconstitutional. First and foremost, this independence is manifested in the self-determination of financial needs. In case of necessity to reduce the amounts provided for the functioning of constitutional bodies, representatives of all political forces make decisions to charge the government, together with the heads of constitutional bodies, under the general agreement and considering the existing financial difficulties, to determine the reduction of expenses in the budget of the constitutional body (Skomorokha, 2016).

In other scholarly works, on the basis of considering guarantees of independence of the CCU, V. Ye. Skomorokha concludes that the budget financing of the Court should include the following points: 
1. In order to ensure the budget autonomy and financial management of the Constitutional Court, the estimation of its expenditures should guarantee the possibility of independent constitutional justice and cannot be reduced compared to the previous fiscal year.

2. If the Cabinet of Ministers of Ukraine considers it necessary to reduce the total expenses of the CCU, then proportionally (in percentage terms) the total funding of other branches of power should be decreased. The discussion should involve the Head of the Court. In case of disagreement, the proposals of the Head of the CCU are included in the draft budget with the conclusion of the Cabinet of Ministers of Ukraine.

3. The funding level for the next year should be discussed in the parliament with the participation of the Head of the CCU or his deputy.

4. Costs of maintenance of the CCU may be attributed to protected items of the budget.

5. Management of budget funds for the support and maintenance of the CCU functioning in accordance with the estimation approved by the Court shall be exercised by the Head of the CCU without the influence of other branches of power.

Therefore, observance of the principle of financial independence of the Constitutional Court depends on the economic capabilities of the state, the level of legal culture of senior officials, and a number of other factors of objective and subjective character (Skomorokha, 2016).

According to M.V. Savchyn, the basis of financial and material support for the independence of the court is the implementation of the pro rata principle in financing the maintenance of judicial institutions, which enables fair allocation of expenditures for their maintenance, necessary for ensuring the right of defence (consequently, process of law), the rights of the person to judicial protection. In its disposition of the case on financing of the courts, the CCU stated that the restriction of expenditures for the financing of the judiciary does not guarantee the proper conditions for the full and independent implementation of justice and the functioning of courts and undermines the trust of citizens in state power, endangers the consolidation and protection of fundamental human and civil rights and freedoms. In case of a deficit of the State Budget of Ukraine, the reduction of expenditures for the financing of courts should be conducted on the pro rata principle, with the consent of the CCU and the Supreme Court of Ukraine (Savchyn, 2003). In addition, M. V. Savchyn suggests that the Rules of the CCU should reflect the provisions of the Law of Ukraine "On the Constitutional Court of Ukraine” as of October 16, 1996, regarding the proposals on the total financing of the Court when drafting the State Budget of Ukraine (Article 31). The CCU has already expressed its position on the issue offinancing of courts but these issues should be regulated clearly in the Rules of Court to increase the guarantees of independence of the body of constitutional justice (Savchyn, 2003).

M.F. Selivon notes that the Secretariat drafts estimations for the CCU for the next year. It is examined in the Permanent Committee of the Court on Budget and Personnel and approved by the CCU (Clause 1, Section 7, Chapter 2 of the Rules of the CCU). Subsequently, the Head of the CCU transmits this document to the Cabinet of Ministers of Ukraine and the Verkhovna Rada of Ukraine. The analysis of the procedure and justification of the draft budget for financing the CCU in the Ministry of Finance of Ukraine, the Cabinet of Ministers of Ukraine, committees of the Verkhovna Rada of Ukraine, as well as the approval of the budget at the plenary session of the Parliament, reveals that provided for in the legislation guarantees of financial independence of the Court at these stages of the budget procedure are insufficient. While the above-mentioned bodies discuss the budget of the CCU, in essence, decisions taken do not consider the special status of the latter and the procedure is the same as for other state bodies and budgetary institutions (Selivon, 1998).

The analysis of the previous version of the Law of Ukraine "On the Constitutional Court of Ukraine" on October 16, 1996, from retrospective, suggests that financing of the CCU has been a separate line in the State Budget of Ukraine. Proposals on the total financing of the CCU and the draft budget were submitted by the Head of the Court to the Cabinet of Ministers of Ukraine and the Verkhovna Rada of Ukraine when drafting the State Budget of Ukraine for each subsequent year (Pro Konstytutsiynyi Sud Ukrainy Zakon Ukrainy). In a popular commentary to the above Article 31 of the Law of Ukraine "On the Constitutional Court of Ukraine" as of October 16, 1996, S. L. Lysenkov notes that after the approval of the Verkhovna Rada of Ukraine, the State Budget becomes a law. The total funds allocated to finance the activities of the CCU are as a separate line in it and gain the power of the law, and therefore, cannot be changed by any government bodies or officials (Lysenkov, 1998). The Head of the CCU leads and organizes its performance and better than anyone else knows its needs. That is why the law empowers him to submit proposals to the Cabinet of Ministers of Ukraine and the Verkhovna Rada of Ukraine regarding the total financing of the CCU together with the draft of the corresponding estimations (Lysenkov, 1998).

The scientific and practical comments of the Law of Ukraine "On the Constitutional Court of Ukraine" on October 16, 1996, under the general editorship of A. A. Stryzhak state that according to Part 1 of Article 31 of this Law, the financing of the CCU in a separate line in the State Budget is one of the guarantees of independence of the single constitutional jurisdiction body. According to the Decision of the Constitutional Court of Ukraine no. 6-rp as of June 24, 1999 (a case on financing of courts), the centralized procedure for 
financing of the judiciary from the State Budget of Ukraine to ensure the proper economic conditions for full and independent implementation of justice, financing of court needs (expenses for consideration of court cases, utilities, repair and security of court premises, purchase of office equipment, postal expenses, etc.) should limit any influence on the court and is aimed at guaranteeing judicial activity consistent with the principles and requirements of the Constitution (Stryzhak, 2009). According to subparagraph 3, clause 1 , Section 2 of the Rules, the Head of the CCU submits for the approval of the Court draft estimates for each subsequent year. At its meetings, the CCU considers proposals regarding the total financing of the Court, approves the draft estimates for each fiscal year; hears the information of the Head of the CCU on the use of budget allocations (Subparagraphs 7, 9, Clause 1, Section 7) (Stryzhak, 2009).

The reform of the domestic constitutional justice in 2016-2017 included the introduction of changes to financial ability and independence of the CCU. According to Article 1481 of the Constitution of Ukraine on June 28, 1996, the state provides the CCU with financing and appropriate conditions for the activity. The State Budget of Ukraine determines separately the expenses for the activity of the Court considering the proposals of its Head. The size of the remuneration of the CCU judge is provided for by the law on the CCU (Konstytutsiia Ukrainy), and not by government decrees as before (Kyrychenko, June 2017). Furthermore, Article 48 "Guarantees of the financial independence of the Court" of the Law of Ukraine "On the Constitutional Court of Ukraine" as of July 13, 2017, stipulates that expenditures on the financial support of the Court's activity are determined by a separate line in the State Budget of Ukraine. Expenditures for financial support of the Court's activities cannot be reduced in the current budget period. The total expenses for financing the Court's activities in the next year may not be lower than the expenditures in the preceding fiscal year. The Court, in accordance with the Budget Code of Ukraine, functions as the main spending unit of the State Budget of Ukraine regarding the financial provision of its activities (Pro Konstytutsiynyi Sud Ukrainy). It is important to ensure the tradition of effective application and practical implementation of these regulations in the activities of the Verkhovna Rada of Ukraine and the Cabinet of Ministers of Ukraine.

Thus, according to the annual information report of the CCU for 2017, the Law of Ukraine "On the State Budget of Ukraine for 2017" as of December 21, 2016, the court has been designated as the main spending unit under the budget program 0801010 "Ensuring Constitutional Jurisdiction in Ukraine". The strategic objective of the Court as the main spending unit is to ensure compliance and implementation of the constitutional regulations, human and civil rights and freedoms, the principles of the social and state system in Ukraine, person's access to constitutional control. The total expenditures of the CCU as the main spending unit in 2017 amounted to 148485.1 thousand UAH, including: current expenditures up to 131070.0 thousand UAH, capital expenditures up to 17415.1 thousand UAH. Unlike previous years, in 2017, the CCU received the necessary capital resources to upgrade the material and technical base to create the prerequisites for the effective implementation of the new strategic task, that is, to increase access of citizens and other persons to the constitutional justice and to implement powers of constitutional complaints handling. Due to development expenditures, in 2017, the capital repairs of some premises of the administrative building of the CCU with the functional complex arrangement (meeting room, consultation room, and hardware technical office) were carried out to ensure one of the Court Senate functioning, and three halls of meetings of the Chamber of the CCU were also arranged. An important trend in using financial resources in 2017 is the comprehensive modernization and updating of the information and communication systems of the CCU. An important step towards the implementation of the principles of transparency and openness of the CCU was the introduction, on a new technical basis, of an online broadcast of open parts of the plenary sessions of the Court for citizens of Ukraine and other individuals to obtain information on the work of the CCU directly.

In view of the strategic objective, some unsolved issues in 2017 on the financial support of constitutional proceedings should be also noted. In particular, the issue of cost planning on the involvement of experts, specialists and translators is problematic due to the lack of appropriate legal regulation. In addition, the mechanism of compensation of expenses incurred by witnesses involved in the constitutional proceeding remains unresolved. In accordance with the Law of Ukraine "On the Constitutional Court of Ukraine" as of July 13, 2017, the Archive and Library of the CCU are created and function. These institutions should become public and accessible centres for professionals, scholars, and all interested persons. However, the conditions for ensuring such publicity in the CCU have not been created. There are neither premises of the relevant technical standard, nor sufficient financing aimed at developing a library fund and improving the special technical conditions for storing cases of constitutional proceedings up to 100 years. To solve these problems, the provided plan for the CCU functioning should be implemented, that is, the three buildings of the Court should operate, of which only two are currently under construction (Shchorichna informatsiyna dopovid Konstytutsiynoho Sudu Ukrainy za 2017 rik).

It should be noted that the regulation of Article 48 of the Law of Ukraine "On the Constitutional Court of Ukraine" on July 13, 2017, according to which the 
total financing of the activities of the CCU for the next year cannot be less than the total expenditures in the previous fiscal year, is not fully consistent with one of the main principles of the budget the system of Ukraine, that is, the principle of justification. Therefore, failure to comply with this provision may cause the unproductive use of funds, excessive overstatement of needs. For that reason, the current legislation regulates issues of organizational support for the activities of the CCU, while certain provisions of the legislation in determining the total financing of the activities of the Court need to be improved (Zvit pro rezultaty finansovoho audytu Konstytutsiynoho Sudu Ukrainy).

\section{Conclusions}

Therefore, the analysis conducted enables to assert that the characteristic feature of socio-political transformations in modern Ukrainian society is ongoing reformation of constitutional justice, one task of which is to strengthen the financial independence of the CCU as potentially the most effective institution for the protection of human and civil rights and freedoms, establishment of legal, constitutional Ukraine. Ultimately, all reforms must serve the main public interest, that is, the wellness of a person who should live in conditions of guaranteed rights and freedoms, a high level of culture, science and education, material security, peace and safety (Kryvytskyi, 2018). With the enactment of the Law of Ukraine "On Amendments to the Constitution of Ukraine (on Justice)" as of June 2, 2016, and according to the recommendations of the European Commission for Democracy through Law (the Venice Commission), the CCU acquired the status of an independent institution that is different from the courts of general jurisdiction. Consequently, the status of a judge of the CCU, the procedure for selecting candidates for this post have been changed, as well as an exhaustive list of grounds for dismissal of the judge of the Court has been provided for and the jurisdiction of the CCU to terminate the powers of the judge of the Court has been extended. In addition, the Basic Law of Ukraine contains the CCU regulations aimed at strengthening the independence, which guarantee the financing of the Court and appropriate conditions for its activities. The current legislation regulates the issue of financial independence of the CCU. Moreover, the practical application of the Article 48 of the Law of Ukraine "On the Constitutional Court of Ukraine" on July 13, 2017, regarding the determination of expenditures not less than the expenditures in the previous fiscal year, needs to be reconciled with one of the basic principles of the budgetary system of Ukraine, the principle of justification.

\section{References:}

Fedorenko, V. (2015). Ponovlennia avtorytetu Konstytutsiynoho Sudu Ukrainy yak zaporuka efektyvnoho funktsionuvannia derzhavy [The renewal of the authority of the Constitutional Court of Ukraine as a guarantee of the effective functioning of the state]. Pravo Ukrainy, 5, 97-110. (in Ukrainian)

Kuzmenko, O. O. (2012). Konstytutsiynyi Sud Ukrainy v systemi vyshchykh orhaniv derzhavnoi vlady [The Constitutional Court of Ukraine in the system of supreme bodies of state power] (Dissertation Abstract of $\mathrm{PhD}$ in specialty 12.00.02 Constitutional Law; Municipal Law). K., 20 p. (in Ukrainian)

Chupryna, L. (2006). Biudzhet Konstytutsiynoho Sudu Ukrainy - odna z harantiy zdiysnennia konstytutsiynoi yurysdyktsii v Ukraini (finansovo-pravovyi aspekt) [The budget of the Constitutional Court of Ukraine is one of the guarantees of the implementation of constitutional jurisdiction in Ukraine (financial-legal aspect)]. Visnyk Konstytutsiynoho Sudu, 3, 37-42. (in Ukrainian)

Skomorokha, V. Ye. Konstytutsiynyi Sud Ukrainy v mekhanizmi derzhavnoi vlady [The Constitutional Court of Ukraine in the mechanism of state power] (Dissertation of $\mathrm{PhD}$ in specialty 12.00.02). Kh., 230 p. (in Ukrainian)

Skomorokha, V. (2006). Nezalezhnist Konstytutsiynoho Sudu Ukrainy ta ii harantii. Biudzhetne finansuvannia naivazhlyvisha harantiia yoho samostiynosti ta nezalezhnosti [Independence of the Constitutional Court of Ukraine and its guarantees. Budget financing the most important guarantee of his independence and independence]. Visnyk Konstytutsiynoho Sudu Ukrainy, 3, 10-24. (in Ukrainian)

Savchyn, M. V. (2003). Konstytutsiynyi sud Ukrainy yak harant konstytutsiynoho ladu [Constitutional Court of Ukraine as a guarantor of the constitutional order] (Dissertation of PhD in specialty 12.00.02). K., 218 p. (in Ukrainian)

Selivon, M. F. (1998). Problemni pytannia formuvannia i vykonannia biudzhetu Konstytutsiynoho Sudu Ukrainy [Problematic Issues in the Formation and Execution of the Budget of the Constitutional Court of Ukraine]. Visnyk Konstytutsiynoho Sudu Ukrainy, 5-6, pp. 91-98. (in Ukrainian)

Pro Konstytutsiynyi Sud Ukrainy Zakon Ukrainy [On the Constitutional Court of Ukraine]. Law of Ukraine no. 422/96-VR ofOctober 16, 1996. Retrieved from: http://zakon.rada.gov.ua/laws/show/422/96-\%D0\%B2\%D1\%80

Lysenkov, S. L. (1998). Zakon Pro Konstytutsiynyi Sud Ukrainy: popul. koment. [On the Constitutional Court of Ukraine: The popular cometary]. Zakony Ukrainy. K. : Lybid, 103 p. (in Ukrainian)

Stryzhak, A. A. (2009). Zakon Ukrainy 'Pro Konstytutsiynyi Sud Ukrainy': nauk.-praktych. koment. [The Law of Ukraine "On the Constitutional Court of Ukraine": sciences-practical]. A. A. Stryzhak, Ya. V. Rybalko, M. V. Savchyn (Eds.). K.: In Yure, 328 p. (in Ukrainian)

Konstytutsiia Ukrainy [The Constitution of Ukraine]. No. 254k / 96-VR of 28 June 1996. Retrieved from: http://zakon5.rada.gov.ua/laws/show/254к/96-вp. (in Ukrainian) 
Kyrychenko, Yu. (June 2017). Konstytutsiynyi Sud Ukrainy: problemy zabezpechennia nezalezhnosti: analitychnyi zvit [Constitutional Court of Ukraine: Problems of Independence: Analytical Report]. Retrieved from: https://rpr.org.ua/wp-content/uploads/2017/07/2017-06-25-DRI-BP-CCU_indpn-Almost_final-UA.pdf. (in Ukrainian)

Pro Konstytutsiynyi Sud Ukrainy [On the Constitutional Court of Ukraine]. Law of Ukraine no. 2136-VIII of July 13, 2017. Retrieved from: http://zakon.rada.gov.ua/laws/show/2136-19. (in Ukrainian)

Shchorichna informatsiyna dopovid Konstytutsiynoho Sudu Ukrainy za 2017 rik, zatverdzhena na zasidanni Konstytutsiynoho Sudu Ukrainy Postanovoiu Konstytutsiynoho Sudu Ukrainy Annual information report of the Constitutional Court of Ukraine for 2017, approved at the sitting of the Constitutional Court of Ukraine by the Resolution of the Constitutional Court of Ukraine] (no. 17-p/2018 of March 29, 2018). Retrieved from: http://www.ccu.gov.ua/docs/2064. (in Ukrainian)

Zvit pro rezultaty finansovoho audytu Konstytutsiynoho Sudu Ukrainy, zatverdzhenyi rishenniam Rakhunkovoi palaty [Report on the results of the financial audit of the Constitutional Court of Ukraine, approved by the decision of the Accounting Chamber] (no. 18-2 of September 13). Retrieved from: http://www.ac-rada.gov.ua/doccatalog/ document/16753286/Zvit_18-2_2017.pdf?su. (in Ukrainian)

Kryvytskyi, Yu. V. (2018). Zabezpechennia prav i svobod liudyny ta hromadianyna yak kliuchovyi napriam pravovoi reformy [Ensuring the rights and freedoms of man and citizen as a key area of legal reform]. Prava liudyny i politsiia u suchasnomu sviti: materialy kruhloho stolu, prysviachenoho pamiati S.L. Lysenkova (Kyiv, April 12, 2018). A. M. Zavalnyi, N. V. Lazniuk, M. M. Pendiura et al. (Eds.). K.: FOP Maslakov, 118-122. (in Ukrainian) 